\title{
9 | Popular mobilization, party dominance and participatory governance in South Africa
}

\author{
LAURENCE PIPER AND LUBNA NADVI
}

This chapter seeks to explore the character of popular mobilization in South Africa, mostly at the local level. This is done through exploring the interaction of two independent processes. The first concerns the relative empowerment of political parties and the disempowerment of civil society (especially social movements) by the democratization process in South Africa. The second concerns the introduction of new institutions of public participation in local governance. Hence, while the latter are portrayed as 'invited spaces' in which communities can engage the local state constructively, the poor design of these spaces, a lack of genuine will on the part of elites and the relative power of key social actors mean that, in practice, they are either meaningless processes or simply co-opted by political parties. Notably, civil society has tended either to disengage from the local state and focus on provincial and national levels, or to resort to forms of popular protest to be heard by local government - the non-governmental organization (NGO) sector usually favouring the first approach and social movements the second.

This 'disengaged-enraged' dichotomy reflects clearly the failure of the formal invited spaces for public participation in local governance. Furthermore, it is hard to see how this dynamic will change, even with better-designed invited spaces, until the balance of social forces is restored with the revivification of civil society, and especially social movements. Reasons for optimism include the growing popular disgruntlement at poor delivery of public goods by local government - which is arguably exacerbated by the introduction of meaningless forms of public participation - and evidence of a new crop of local and organic community-based organizations which could form the basis of future social movements. In short, popular mobilization at the local level in South Africa remains dominated by political parties, despite new participatory institutions, although we are witnessing the creation of conditions for new and powerful forms of popular mobilization into the future.

In making this argument, the chapter begins with theoretical literature on state-society relations, and the character of and relationship between 
'invented' and 'invited' spaces. It then moves to the received views in the literature on popular mobilization in recent South African history, and the nature and purpose of new forms of 'participatory governance' at local government level. The relationship between these 'invented' and 'invited' spaces is then explored through case studies of two municipalities, with special focus on the consequences for popular mobilization. The chapter concludes by analysing the causes of demobilization that result from participatory governance, identifying the consequent tendency of civil society to 'disengage' from or become 'enraged' at local government, and pointing to the necessity of oppositional-movement revival to change state-society relations in a more democratic fashion.

\section{Theorizing state-society relations through invented and invited spaces}

In recent years almost every democratic country in the world, regardless of economic development or democratic robustness, has witnessed attempts to enhance public participation in governance, especially local governance. The reasons for this are many and complex, and can be traced to new theories and practices of development (World Bank 1996); new theories and practices of democracy (Cohen 2002; Habermas 2002) and democratization (Mattes 2002); and at the intersection of all of these, new theories and practices of citizenship (Cornwall 2002). Following Cornwall (ibid.: 17), these new participatory institutions and practices can be termed the 'invited spaces' of participatory local governance. These invited spaces would include Hendricks's (2006: 486) 'micro deliberative structures' and Fung and Wright's (2001: 5) 'empowered deliberative democratic structures'. Examples are the participatory city budgeting in Porto Alegre, Brazil; functionally specific neighbourhood councils in Chicago, USA; village governance in Kerala, India; and citizens' juries in the United Kingdom.

Initiated by the local state, invited spaces typically look to draw local communities into processes of consultation, deliberation and sometimes joint decision-making on key local issues. Perhaps just as important in understanding emergent local state-society relations is popular mobilization led 'from below' by civil society or local communities. Hence Cornwall (2002: 17) contrasts the 'invited spaces' created 'from above' by the state with 'organic spaces' created 'from below' by those outside the state. The latter include spaces created from popular mobilization, as well as spaces in which 'like-minded people join together in common pursuits'. Holston and Appadurai (1999) describe the emergence of a 
rights-based citizenship among the urban poor, marginalized by neoliberal governance and mobilized through social movements, which looks to transform social relations from the ground up. Miraftab (2006) paints a picture of 'invented' spaces opposing 'invited' spaces in South Africa, but also elsewhere in the world, for the same reason, the globalization of neoliberal economic policy.

Importantly, as Cornwall and Coelho (forthcoming: 1) indicate, the conceptualization of local state-society relations is not exhausted by a binary opposition between top-down, state-driven, invited spaces and bottom-up, social-movement-driven, invented spaces. Hence they talk of a 'participatory sphere' that lies at the interface of the public sphere and the state, composed of hybrid institutions, some of which are extensions of the state and some of which are claimed from the state. The critical point is that the relationship of these institutions with the state and the general public is partial: 'its institutions have a semi-autonomous existence, outside and apart from the institutions of formal politics and everyday associational life ... They are spaces of contestation, but also of collaboration and co-operation ...'. Lastly, but most importantly, Gaventa (2007: 2) points out that international experience shows that a functioning participatory sphere or meaningful public participation in local governance requires three things: good institutional design, political will to make it happen and a strong civil society.

These theoretical reflections matter to the South African case precisely because the last ten years have witnessed a process of institutional reform of local governance in the name of greater public participation on issues related to the delivery of key social goods. Hence there are very specific and identifiable 'invited spaces' that have the potential, in theory, to both engender more constructive and democratic state-society relations and enhance the delivery of social goods. At the same time, there is a particular history of social mobilization in South Africa around the liberation struggle which has empowered political parties at the expense of civil society and especially social movements. It is this particular dialogue between 'invented' and 'invited' which we wish to explore and characterize. In the following section we outline this history of popular mobilization, and then move to outline the democratic reforms of local governance.

\section{Invented spaces: the changing patterns of popular mobilization in South Africa}

With the formal deracialization and democratization of South Africa in the early 1990s, the fundamental shape of inclusion and exclusion 